\title{
Mechanical Behavior of an Ultisol Under Different Sugarcane Management Systems in Brazil
}

\author{
Wagner Luís da Silva Souza ${ }^{1}$, José Ramon Barros Cantalice ${ }^{2 *}$, Brivaldo Gomes de Almeida², Romero Falcão \\ Bezerra Vasconcelos ${ }^{2}$ and Apolino José Nogueira da Silva ${ }^{3}$ \\ ${ }^{1}$ Federal Institute of Pernambuco and researcher of the PNPD Program (CNPq/FACEPE) join to Rural Federal of Pernambuco University, Brazil
}

${ }^{2}$ Soil Conservation Engineering Laboratory, Rural Federal of Pernambuco University (UFRPE), Brazil

${ }^{3}$ Federal of Rio Grande do Norte University, BRAZIL (UFRN)

*Corresponding author: José Ramon Barros Cantalice, Soil Conservation Engineering Laboratory, Rural Federal of Pernambuco University (UFRPE), Brazil.
Received Date: June 04, 2020

Published Date: July 31, 2020

\begin{abstract}
Compressibility and shear strength in agricultural soils are associated with pressures exerted on the soil surface by the intensive use of machines. This study aimed to evaluate the mechanical behavior of an Ultisol cultivated with sugarcane under the application of sugarcane residues (vinasse and filter cake) and compare it with an Atlantic Forest soil. Uniaxial compression tests were performed through the application of increasing with pressures from 12.50 to $1,600 \mathrm{kPa}$, at three water contents in undisturbed samples from the layers of 0-0.20 and 0.20-0.40 m, and for shear direct test were collected in the layers of $0-0.20 \mathrm{~m}$ and, subjected to three water content levels and four levels of normal tensions of direct shear. The higher content of total organic carbon in the soil under native forest (2.42 g kg-1) allowed higher pre-compression stresses (101.21-143.55 kPa) due to an increase in soil cohesion from 22.58 to $61.23 \mathrm{kPa}$, with the reduction in the volumetric water content. Thus, this natural condition was significantly different from the management systems, with respect to the mean values of cohesion, by Tukey test $(\mathrm{p}<0.05)$. The application of filter cake and vinasse for 25 years significantly favored the dissipation of pre-compression stress in the soil, compared with the soil under native forest. The system with filter cake application showed higher shear strength from the tension of $100 \mathrm{kPa}$ on, with values from 120 to $190 \mathrm{kPa}$, in comparison to the system with vinasse application.
\end{abstract}

Keywords: Compressibility; Shear; Dissipation; Vinasse; Organic fibers

\section{Introduction}

The different management systems in the various agricultural soils, combined with the pressures exerted on the soil surface by the intensive use of agricultural machines and implements, are capable of causing variations in soil physical-chemical properties, which have great influence on its mechanical behavior [1-3].

The compressibility of agricultural soils in the literature is presented with various definitions, but all of them explain that the process is characterized by a variation in soil volume and increase of its density in response to a pressure applied on its surface $[4,5]$. According to Braida et al. [6], plant residues applied on soil sur face absorb part of the compaction energy produced by the traffic of machines and animals. Therefore, during the compression, plant residues deform and dissipate the energy, thus not transferring this energy completely to the soil. Thus, the total transfer of this energy will only occur when the residue is no longer efficient at absorbing all the compressive energy, when its total deformation occurs.

Considering a soil mass, unsaturated, being subjected to external load (P), inside it will develop pressures in the phase solid $\left(\mathrm{p}_{\mathrm{s}}\right)$, liquid $\left(\mathrm{p}_{\mathrm{w}}\right)$ and gaseous $\left(\mathrm{p}_{\mathrm{g}}\right)$. The distribution of pressures is shown schematically in Figure 1. 


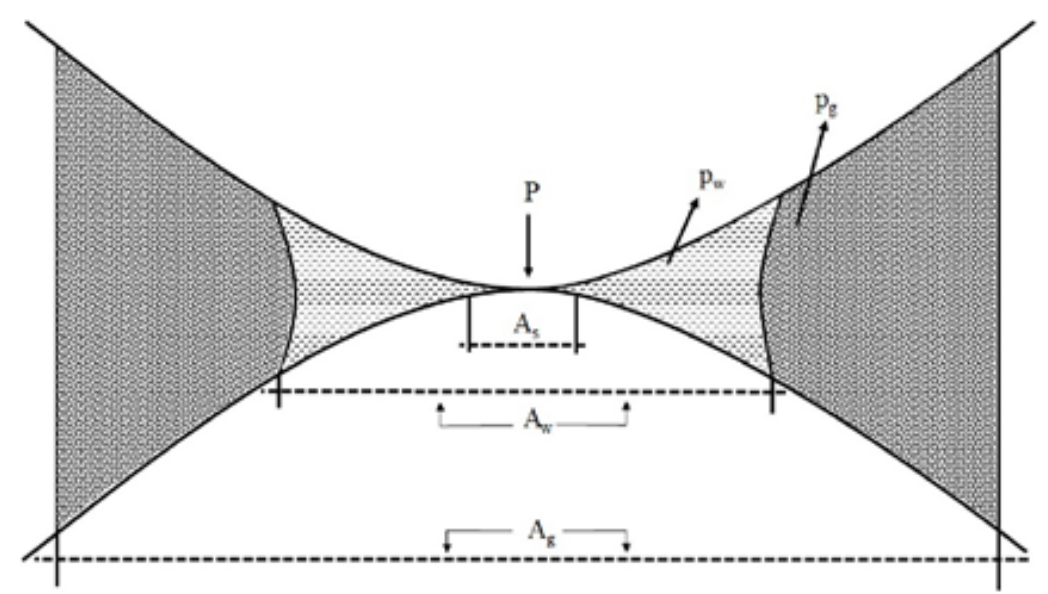

Figure 1: Distribution of the stresses in the phases solid, liquid and gaseous in unsaturated soils when submitted to normal load. Source: Caputo [9] modified.

Considering two solid particles in contact with a surface area As and the total force (load) normal to the plane of contact, in equilibrium condition, have:

$$
P=p_{s}+p_{w}+p_{g}
$$

then, assuming that $\mathrm{P}$ is the total resulting force normal to the plane of contact between two soil particles, from the indications in Figure 1 it may be deduced that:

$$
P=\left(p_{s} \bullet A_{s}\right)+\left(p_{w} \bullet A_{w}\right)+\left(p_{g} \bullet A_{g}\right)
$$

thus, by dividing equation (2) by the total area (A), have:

$$
\frac{P}{A}=p_{s} \cdot \frac{A_{s}}{A}+p_{w} \cdot \alpha \frac{A_{w}}{A}+p_{g} \cdot \frac{A_{g}}{A}
$$

where: $\mathrm{P}=$ normal total force at the point of contact; $\mathrm{ps}=$ force acting on the solid phase; $\mathrm{pw}=$ force acting on the liquid phase $\mathrm{p}_{\mathrm{g}}=$ force acting on the gaseous phase; $\mathrm{A}=$ total area; $\mathrm{Aw}=$ area of the liquid phase; $A s$ = area of the solid phase; $A_{g}=$ area of the gaseous phase.

Assuming that the relation $\mathrm{P} / \mathrm{A}=\sigma, \mathrm{As} / \mathrm{A}=$ ' $\mathrm{a}$ ' and, $\mathrm{Aw} / \mathrm{A}=\mathrm{X}$, may rewrite equation (3) as:

$$
\sigma=p_{s} \bullet \alpha+(1-\alpha) \cdot p_{g}-X \cdot\left(p_{g}-p_{w}\right)
$$

Considering that ' $a$ ' is little, so (1-a) $\rightarrow 1$; and that, on the contrary, $p_{s}$ is high, so by making a. $p_{s}=\sigma>$ (effective pressure), may rewrite equation (4), obtaining:

$$
\sigma^{\prime}=\sigma-p_{g} X \cdot\left(p_{g}-p_{w}\right)
$$

where: $\sigma^{\prime}=$ effective pressure at the point of contact; $\sigma=$ normal pressure in the contact plane; $\mathrm{p}_{\mathrm{g}}=$ pressure acting on the air and $\mathrm{X}=$ coefficient of resistance proportional to the degree of saturation of the soil, being equal to one for the saturated soil and equal to zero for the dry soil and $\mathrm{p}_{\mathrm{w}}=$ working pressure in the meniscus of water.
Equation (5) represents the principle of effective pressures, proposed by Terzaghi [7] and generalized, for unsaturated soils by Bishop [8]. For unsaturated soils, Tower \& Childs [9] and Tower [10] demonstrated that the effective stress or pressure $(\sigma>)$ may be determined by expression (6):

$$
\sigma^{\prime}=-X \cdot\left(\psi_{m}\right)
$$

where: $\Psi \mathrm{m}$ is the soil matrix suction, and " $\mathrm{X}$ " is the resistance parameter.

Mosaddeghi et al. [11], using equation (6), concluded that the increase in soil resistance, defined by the pre-compression voltage and, due to soil matrix suction, can be explained in terms of effective stress $(\sigma>)$. Caputo [12] emphasizes that all measurable effects of variations in soils, such as compression, distortion and shear strength are due to variations in the effective stresses. According to Braida [13], when the effective stress resulting from the application of normal load on the soil surface exceeds the shear strength at the points of contact between the particles, the compression and deformation processes become eminent.

Shear strength is the resistance $(\tau)$ that the soil can offer to shear stresses in its matrix or structure, and it is directly related to the cohesion forces between soil particles and to cohesion parameters and the angle of internal friction. Other intrinsic properties of the soil, such as clay content and organic matter are also directly related to soil resistance to shear $[14,15]$.

The effects of soil organic matter on shear parameters are somehow controversial. Some studies [16,17] reported a decrease in shear tension with the increase of soil organic matter due to its capacity to decrease soil density, leading to a reduction in shear strength. On the other hand, soil organic matter increases the cohesion forces between soil particles, which is directly related to soil shear strength [18]. Other studies [13-21] reported increase in 
soil shear strength with the increase of organic matter in cultivated soils.

Soil mechanical behavior tends to show different values according to the variability of the properties of cultivated soils under different management systems. In Brazil, the types of soil cultivated with sugarcane range from Entisols Quatzipsamments to Oxisols, the latter of which, along with Ultisols, are the most representative soils in the Northeast region [22]. In the state of Pernambuco, the soils of most areas cultivated with sugarcane are Ultisols, Oxisols and, in lower proportion, Gleysols and Spodosols.

Given the above, this study aimed to evaluate the mechanical behavior of an Ultisol cultivated with sugarcane and subjected to the application of vinasse and filter cake for more than 25 years.

\section{Material and Methods}

\section{Study area}
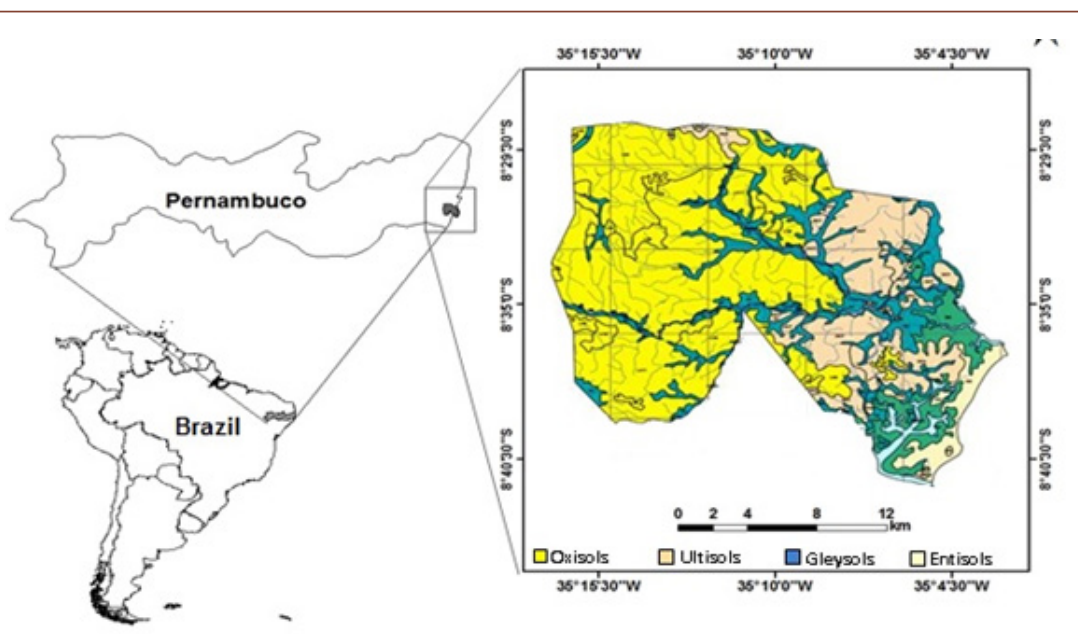

Figure 2: Soil map of the municipality of Sirinhaém-PE [31].

The study was conducted in a sugar and ethanol unit, located in the municipality of Sirinhaém, $80 \mathrm{~km}$ away from Recife-PE, Brazil. Two sugarcane cultivation areas were selected from thereabout 17 hectares each, both with Ultisol, one of the three most predominant soils in the region (Figure 2). The two management systems were the applications of filter cake and vinasse. These systems were compared with an area of native forest, which were located on the slope of the terrain.

\section{History and management of the sugarcane cultivation areas}

The areas have been cultivated for more than 50 years. Vinasse and filter cake have been applied in the areas of the sugar and ethanol unit for approximately 25 years. In the management system with vinasse application, irrigation is performed for $0.5-2 \mathrm{~h}$ in each sprinkler, with water depths ranging from 40 to $45 \mathrm{~mm}$ in the ratoon from the second cut on. In the management system with filter cake application (industrial organic residues from sugar production), approximately $40 \mathrm{t} \mathrm{ha}^{-1}$ of filter cake are applied in the total area during the planting.

Chemical fertilization with N-P-K in the areas under vinasse application is performed only in the ratoon, using $500 \mathrm{~kg} \mathrm{ha}^{-1}$ of the 21-00-00 formulation, exclusively composed of ammonium sulfate. For areas under filter cake application, $500 \mathrm{~kg} \mathrm{ha}^{-1}$ of natural phosphate are applied inside the furrows during the planting and, after 60 days, $500 \mathrm{~kg} \mathrm{ha}^{-1}$ of the 15-00-26 formulation, which is exclusively composed of urea and potassium chloride, are applied as topdressing.

\section{Determination of pressures of the machines on the soil}

The vehicles considered in this study were used in the sugarcane cultivation areas for planting and periodical soil preparation. In these two operations, the characteristics of the vehicles were recorded: five BH-180 tractors, with mean weight of $10 \mathrm{t}$. The front axle consisted of two 18.4-26 Goodyear tires with inflation pressure of $179 \mathrm{kPa}$ and the rear axle consisted of two 24.5-32 Goodyear tires with inflation pressure of $165 \mathrm{kPa}$, both ballasted with $75 \%$ of water. These data were plotted in SoilFlex, where the vertical distribution of contact stresses has all been simulated with a contact area as a super ellipse, according to Keller et. al [23].

The model proposed by Keller et al. [11], using analytical equations for vertical propagation of stresses developed by Boussinesq [24] and Frohlich [25], and uses the approach Soane's [26] to calculate the normal stress. The procedure used by Soane [26] for calculate the load applied by the wheels is to divide the contact area of small elements (i) where each element will have an area $\left(A_{i}\right)$ in which an axial force is exerted $\left(\sigma_{i}\right)$ therefore, the point charges $\sigma_{i} A_{i}$ $=\mathrm{P}_{\mathrm{i}}$. Therefore, the vertical stress at a given depth $\mathrm{z}$ is calculated by Soane's approch [42] by equation (7): 


$$
\theta_{Z}=\sum_{i=0}^{i=n} \frac{\xi \cdot P_{i}}{2 \cdot \pi \cdot \gamma^{2}} \cos ^{\xi-2} \cdot \theta_{i}
$$

where $\xi$ is the concentration factor defined by Frohlich (1934), $r$ is the distance from the load $P$ to the desired point and $\theta$ is the angle between the normal vector of the load and position vector of load. The concentrations of factors used for simulations corresponds to the described by Défossez et al. [27].

\section{Soil compressibility test of soils under drained conditions}

For the compressibility test, soil samples were collected in each management system using rings with dimensions of $\varnothing_{\mathrm{i}}=0.073 \mathrm{~m}$ and $\mathrm{h}=0.026 \mathrm{~m}$, with $\varnothing_{\mathrm{i}} / \mathrm{h}$ ratio corresponding to 2.80 , as recommended by the norm MB 3336/90 of the Brazilian National Standards Organization [28]. The samples were collected in two layers (0-0.20 $\mathrm{m}$ and $0.20-0.40 \mathrm{~m})$ in five replicates on a delineament intirely casualized and were evaluated at three water contents $(0.42$, 0.36 and $0.32 \mathrm{~cm}^{3} \mathrm{~cm}^{-3}$ ), totaling 90 samples for the three management systems.

The test was performed in a loading press with capacity of $1,000 \mathrm{kgf}$ consisted in the application of pressures of $12.50,25.0$, $50.0,100,200,400,800$ and 1,600 $\mathrm{kPa}$, established by the norm
MB 3336/90 [28]. The readings of vertical deformation were performed using a micro comparator in the beginning of each pressure stage, which lasted for $30 \mathrm{~s}$, and the pressure was increasingly applied on the samples. At the end of the test, the samples were dried in an oven at $105^{\circ} \mathrm{C}$ for $24 \mathrm{~h}$.

The data obtained from vertical deformation were inserted in an Excel supplement developed in VBA (Visual Basic for Applications) by Gubiani et al. [29], which makes it possible to calculate the pre-compression pressure and the compression index by Casagrande [30], mathematically operationalized by the Van Genuchten equation [31] (8).

$$
\theta=\theta_{\gamma}+\frac{\left(\theta_{s}-\theta_{\gamma}\right)}{\left[1+(\alpha \cdot \psi)^{n}\right]^{m}} E
$$

Where $\theta=$ is soil water content $\left(\mathrm{cm}^{3} \mathrm{~cm}^{-3}\right) ; \theta_{\mathrm{r}}=$ is soil residual water content, corresponding to permanent wilting point $\left(\mathrm{cm}^{3} \mathrm{~cm}^{-3}\right) ; \theta_{\mathrm{s}}=$ is soil saturated water content $\left(\mathrm{cm}^{3} \mathrm{~cm}^{-3}\right) ; \alpha=$ is a scale parameter inversely proportional to mean pore diameter $(\mathrm{cm}$ $\left.{ }^{1}\right) ; \Psi=$ is soil water potential $(\mathrm{kPa})$ and, $\mathrm{n}$ and $\mathrm{m}$ are shape parameters of soil water retention curve, $m=1-1 / n, 0<m<1$, according to van Genuchten [31].

\section{Direct shear test of soils under drained conditions}

\begin{tabular}{|c|c|c|c|c|c|c|}
\hline \multirow{2}{*}{ Attributes } & \multicolumn{3}{|c|}{$0-0.20 \mathrm{~m}$} & \multicolumn{3}{|c|}{$0.20-0.40 \mathrm{~m}$} \\
\hline & Forest & Filter Cake & Vinasse & Forest & Filter Cake & Vinasse \\
\hline Clay $\left(\mathrm{g} \mathrm{kg}^{-1}\right)$ & $480.67( \pm 9.42)$ & $324.00( \pm 25.81)$ & $369.00( \pm 30)$ & $507.33( \pm 24.94)$ & $454.00( \pm 28.28)$ & $474.00( \pm 28.28)$ \\
\hline $\mathrm{CV}(\%)$ & $(1.96)$ & (7.96) & (1.96) & $(4.91)$ & (6.23) & (5.96) \\
\hline Sand $\left(\mathrm{g} \mathrm{kg}^{-1}\right)$ & $504.41( \pm 14.63)$ & $608.20( \pm 49.84)$ & $628.45( \pm 30)$ & $428.54( \pm 16.27)$ & $474.75( \pm 24.41)$ & $513.55( \pm 26.40)$ \\
\hline CV (\%) & $(1.29)$ & (8.19) & $(1.96)$ & $(3.79)$ & $(5.14)$ & $(5.14)$ \\
\hline Silt $\left(\mathrm{g} \mathrm{kg}^{-1}\right)$ & $74.66( \pm 20.67)$ & $67.80( \pm 27.50)$ & $12.55( \pm 5.92)$ & $64.13( \pm 38.09)$ & $71.25( \pm 29.32)$ & $12.45( \pm 4.76)$ \\
\hline CV (\%) & $(27.69)$ & $(40.57)$ & $(1.96)$ & $(59.4)$ & $(41.15)$ & $(38.25)$ \\
\hline $\mathrm{Dp}\left(\mathrm{g} \mathrm{cm}^{-3}\right)$ & $2.51( \pm 0.04)$ & $2.50( \pm 0.09)$ & $2.48( \pm 0.08)$ & $2.49( \pm 0.01)$ & $2.55( \pm 0.04)$ & $2.58( \pm 0.08)$ \\
\hline CV (\%) & $(1.57)$ & (3.74) & $(1.96)$ & $(0.58)$ & $(1.64)$ & $(3.07)$ \\
\hline Ds $\left(\mathrm{g} \mathrm{cm}^{-3}\right)$ & $1.17( \pm 0.07)$ & $1.58( \pm 0.13)$ & $1.63( \pm 0.21)$ & $1.36( \pm 0.08)$ & $1.61( \pm 0.01)$ & $1.61( \pm 0.08)$ \\
\hline CV (\%) & $(5.82)$ & $(8.29)$ & $(1.96)$ & $(6.03)$ & $(0.74)$ & $(4.86)$ \\
\hline $\mathrm{P}_{\mathrm{T}}\left(\mathrm{g} \mathrm{cm}^{-3}\right)$ & $55.31( \pm 0.03)$ & $42.88( \pm 0.02)$ & $36.17( \pm 0.02)$ & $52.89( \pm 0.04)$ & $43.38( \pm 0.01)$ & $39.40( \pm 0.03)$ \\
\hline CV (\%) & $(15.66)$ & (5.89) & $(1.96)$ & $(7.66)$ & $(2.08)$ & $(8.33)$ \\
\hline $\mathrm{MWD}_{\mathrm{D}}(\mathrm{mm})$ & $2.97( \pm 0.03)$ & $2.64( \pm 0.16)$ & $2.38( \pm 0.31)$ & $2.45( \pm 0.10)$ & $2.81( \pm 0.08)$ & $2.83( \pm 0.18)$ \\
\hline CV (\%) & $(2.22)$ & $(6.16)$ & $(1.96)$ & $(4.19)$ & $(2.89)$ & $(6.32)$ \\
\hline$\Theta_{\mathrm{FC}}\left(\mathrm{cm}^{3} \mathrm{~cm}^{-3}\right)$ & $0.40( \pm 0.05)$ & $0.27( \pm 0.02)$ & $0.24( \pm 0.02)$ & $0.40( \pm 0.02)$ & $0.33( \pm 0.01)$ & $0.32( \pm 0.01)$ \\
\hline CV (\%) & $(1.55)$ & $(7.8)$ & $(1.96)$ & $(4.5)$ & $(3.35)$ & $(3.64)$ \\
\hline$\Theta_{\mathrm{PWP}}\left(\mathrm{cm}^{3} \mathrm{~cm}^{-3}\right)$ & $0.32( \pm 0.03)$ & $0.20( \pm 0.02)$ & $0.17( \pm 0.02$ & $0.34( \pm 0.01)$ & $0.27( \pm 0.01)$ & $0.25( \pm 0.01)$ \\
\hline CV (\%) & $(9.14)$ & $(11.06)$ & $(1.96)$ & $(3.51)$ & $(5.03)$ & $(4.58)$ \\
\hline \multirow[t]{2}{*}{ TOC $\left(\mathrm{g} \mathrm{kg}^{-1}\right)$} & $2.42( \pm 2.57)$ & $1.32( \pm 1.74)$ & $1.04( \pm 1.16)$ & $2.52( \pm 1.56)$ & $0.91( \pm 1.90)$ & $0.82( \pm 1.48)$ \\
\hline & $(10.65)$ & $(13.15)$ & $(1.96)$ & $(6.21)$ & (20.78) & (18.09) \\
\hline
\end{tabular}

Table 1: Physical characterization of the Ultisol in the studied area.

$\mathrm{Dp}=$ Soil particle density; $\mathrm{Ds}=$ Soil bulk density; $\mathrm{MWD}_{\mathrm{D}}=$ dry mean weight diameter; $\mathrm{P}_{\mathrm{T}}=$ Total porosity; $\theta_{\mathrm{FC}}=$ volumetric water content at field capacity; $\theta_{\mathrm{PWP}}=$ volumetric water content at the permanent wilting point; $\mathrm{TOC}=$ total organic carbon in the soil; $\mathrm{CV}=$ coefficient of variation; $\pm=\mathrm{Standard}$ deviation 

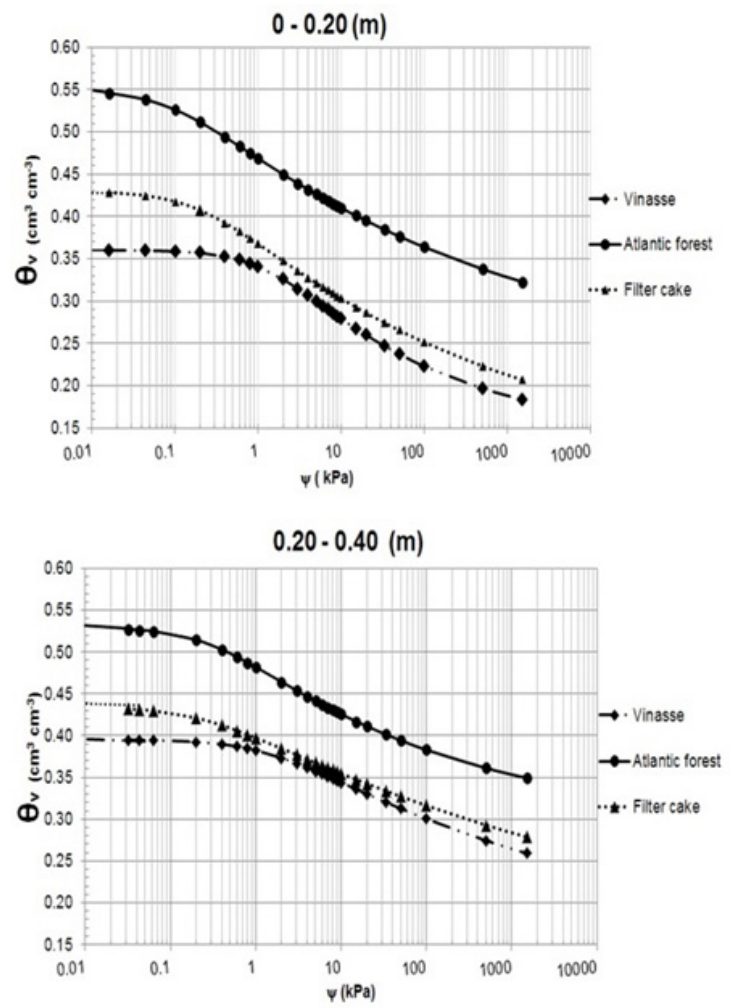

Figure 3: Soil water retention curves.

Samples were collected in the layer of $0-0.20 \mathrm{~m}$ in all management systems using a stainless steel box, with dimensions of 0.06 (w) x 0.06 (l) x 0.043 (h) $\mathrm{m}$. Three repetition were collected in each management system on a delineament intirely casualized, which were used in each normal tension $(50,100,150$ and $200 \mathrm{kPa})$ for the established water contents $\left(0.42,0.36\right.$ and $\left.0.32 \mathrm{~cm}^{3} \mathrm{~cm}^{-3}\right)$, totaling 108 samples. In the laboratory, the excess of soil was removed and saturated for $48 \mathrm{~h}$. Then, the tension table and/or Richards' chamber were used according to the tensions applied in the samples, which were removed after the drainage stopped, thus establishing the potential equilibrium according with metod's Richard et al. [32] (Table 1).

The direct shear test was performed according to the norm D-3080/98 of the American Society for Testing and Materials [33], conducted in a direct shear device with shear velocity of $0.125 \mathrm{~mm}$ $\mathrm{min}^{-1}$, four stages of normal tensions and the three water contents previously mentioned.

At the end of the test, the data required in Equations (9) and (10) were obtained.

$\sigma=\frac{N}{a}$

where: $\sigma=$ normal stress $\left(\mathrm{kgf} . \mathrm{cm}^{2}, \mathrm{kPa}\right) ; \mathrm{N}=$ normal force applied on the test body (kgf, N); a = area of the transversal section of the sample $\left(\mathrm{cm}^{2}\right)$;

$$
\tau=\frac{T}{a}
$$

where: $\tau=$ shear stress (kgf.cm², $\mathrm{kPa}$ ); $\mathrm{T}=$ force applied on the test body (kgf, N); a = area of the transversal section of the sample $\left(\mathrm{cm}^{2}\right)$;

Soil cohesion was determined using the value of direct shear stress in each normal stress at the end of the test, by plotting a graph with the relation shear stress $\mathrm{x}$ normal stress. Cohesion values were obtained by the intercept of the equation.

\section{Sample collection for soil physical tests}

The collection of soil samples for the determinations of soil bulk density, total porosity and soil water retention curve was performed in the layers of 0-0.20 m and 0.20-0.40 m, with five repetition on delineament intirely casualized in each management system, totaling 30 samples for all the management systems. The collection of undisturbed soil samples was performed using an Uhland soil sampler and volumetric rings with height (h) of $0.05 \mathrm{~m}$ and internal diameter $\left(\emptyset_{\mathrm{i}}\right)$ of $0.05 \mathrm{~m}$. In addition, the same number of disturbed soil samples was also collected for the tests of granulometry was carried out by the methodology proposed by Gee et al.[34], particle density and bulk soil by methodology of proposed by Black \& Hartge [35] the mean diameter of soil aggregates [36].

\section{Statistical analysis}

It was used a delineament intirely casualized. The data were subjected to verification of normal distribution, homoscedasticity and the assumptions of the analysis of variance. Then, the analysis of variance (ANOVA) was performed and means were compared by 
Tukey test at $5 \%$ of probability, using the statistical program SAS, version student 2.0 .

\section{Results}

\section{Soil water retention curve of the management systems}

According to the inflection point $(\alpha=1 / \Psi)$ of the soil water retention curve (Figure 3), which corresponds to the tension value at which there is exit of water and consequently the entry of air, in both layers, there was an expressive variation between soils under native forest and sugarcane cultivation. In the native forest system, the inflection point occurred at a more negative matric potential, thus difficulty water drainage with the application of the tensions. The exit of water, and consequent air entry, in the systems under native forest and filter cake application occurred at tensions above $1.0 \mathrm{kPa}$. The soil under Atlantic forest was observed a very expressive change compared to soil under agricultural cultivation, probably the highest content of total organic carbon (Table 2), may have allowed greater retention of water on high matrixial tensions when compared to the other management systems, once, for all systems are within of the same soil class. medium textured soils according EMBRAPA [37].

It is also observed that the volumetric water content selected in the study $\left(0.32 ; 0.36\right.$ and $\left.0.42 \mathrm{~cm}^{3} \mathrm{~cm}^{-3}\right)$ are nearby to field capacity (Table 1) in either management systems. Thereby, it was decided to establish the same level of volumetric water content the samples under study in order to "isolate" the effect that the increase in the amount of organic matter (OM) has on the increase in the water content retained in the same voltage [25] in both soils under study. Thus, it was possible to equalize the samples in the same volumetric water content in the different levels of tension.

\section{Pre-compression stress $(\sigma p)$ and prediction parameters determined under drained conditions}

In the layer of $0-0.20 \mathrm{~m}$, the soil under native forest showed higher values of pre-compression stress $(\sigma p)$, from 101.21 to $143.55 \mathrm{kPa}$ (Table 2), in comparison to the soils cultivated with sugarcane under vinasse and filter cake application. In addition, it showed a reduction in $\sigma_{\mathrm{p}}$, from 143.55 to $101.21 \mathrm{kPa}$, with the increase in the volumetric water content from 0.32 to $0.42 \mathrm{~cm}^{3} \mathrm{~cm}^{-3}$. The values of $\sigma_{\mathrm{p}}$ with the reduction in water contents are within the range considered from high to high, according to the classification of Horn \& Fleige [14]. A more stable organic matter (humus) probably contributed to the increase in soil resistance to compression in the native forest soil, compared with the systems with filter cake and vinasse application. These systems showed contents of total organic carbon (TOC) in the soil of 1.32 and $1.04 \mathrm{gkg}^{-1}$, respectively, thus differing significantly $(\mathrm{p}<0.05)$ from the highest TOC content $\left(2.42 \mathrm{gkg}^{-1}\right)$, observed in the native forest system.

Table 2: Pre-compression stress of an Ultisol under Atlantic forest and sugarcane cultivation with the application of filter cake and vinasse.

\begin{tabular}{|c|c|c|c|c|c|c|c|c|c|}
\hline \multirow{3}{*}{$\begin{array}{l}\text { Management } \\
\text { Systems }\end{array}$} & \multirow{3}{*}{ Methods } & \multicolumn{4}{|c|}{$0-0.20(\mathrm{~m})$} & \multicolumn{4}{|c|}{$0.20-0.40(\mathrm{~m})$} \\
\hline & & 0.32 & 0.36 & 0.42 & \multirow{2}{*}{$\begin{array}{c}\text { TOC } \\
\left(\mathrm{g} \mathrm{kg}^{-1}\right)\end{array}$} & 0.32 & 0.36 & 0.42 & \multirow{2}{*}{$\frac{\text { TOC }}{\left(\mathrm{g} \mathrm{kg}^{-1}\right)}$} \\
\hline & & \multicolumn{3}{|c|}{$\sigma p(\mathrm{kPa})$} & & \multicolumn{3}{|c|}{$\sigma p(\mathrm{kPa})$} & \\
\hline \multirow{3}{*}{$\begin{array}{l}\text { Native forest } \\
\text { (Soil) }\end{array}$} & Casagrande & $143.55 \mathrm{Aa}$ & $133.89 \mathrm{Aa}$ & 101.21 Aa & \multirow{3}{*}{$2.42 \mathrm{~A}$} & $144.03 \mathrm{Aa}$ & 221.18 Аа & $104.92 \mathrm{Aa}$ & \multirow{3}{*}{$2.52 \mathrm{~A}$} \\
\hline & DJ \& P & $146.01 \mathrm{Aa}$ & $126.10 \mathrm{Aa}$ & $64.28 \mathrm{Ab}$ & & $159.10 \mathrm{Aa}$ & $176.42 \mathrm{Aa}$ & $138.88 \mathrm{Aa}$ & \\
\hline & IVI & $131.95 \mathrm{Aa}$ & $134.61 \mathrm{Aa}$ & $89.33 \mathrm{Aa}$ & & $132.13 \mathrm{Aa}$ & $167.16 \mathrm{Aa}$ & $105.66 \mathrm{Aa}$ & \\
\hline \multirow{3}{*}{ Filter Cake Soil } & Casagrande & $74.98 \mathrm{Ba}$ & $54.52 \mathrm{Ba}$ & $49.39 \mathrm{Ba}$ & \multirow{3}{*}{$1.32 \mathrm{~B}$} & $155.78 \mathrm{Aa}$ & $105.75 \mathrm{Ba}$ & $82.89 \mathrm{Ba}$ & \multirow{3}{*}{$0.91 \mathrm{~B}$} \\
\hline & DJ \& P & $57.71 \mathrm{Ba}$ & $35.22 \mathrm{Ba}$ & $39.19 \mathrm{Aa}$ & & $157.83 \mathrm{Aa}$ & 112.25 Bab & $98.78 \mathrm{Ab}$ & \\
\hline & IVI & $76.33 \mathrm{Ba}$ & $75.01 \mathrm{Ba}$ & $60.95 \mathrm{Aa}$ & & $145.61 \mathrm{Aa}$ & $94.77 \mathrm{Ab}$ & $81.33 \mathrm{Ab}$ & \\
\hline \multirow{3}{*}{ Vinasse soil } & Casagrande & $76.43 \mathrm{Ba}$ & $73.34 \mathrm{Ba}$ & --------- & \multirow{3}{*}{$1.04 \mathrm{~B}$} & $143.90 \mathrm{Aa}$ & $129.75 \mathrm{Ba}$ & --------- & \multirow{3}{*}{$0.82 \mathrm{~B}$} \\
\hline & DJ \& P & $107.42 \mathrm{ABa}$ & $82.46 \mathrm{ABb}$ & -------- & & $160.42 \mathrm{Aa}$ & $146.43 \mathrm{Ba}$ & -------- & \\
\hline & IVI & $121.76 \mathrm{ABa}$ & $98.37 \mathrm{ABa}$ & -------- & & $150.92 \mathrm{Aa}$ & $133.82 \mathrm{Aa}$ & --------- & \\
\hline
\end{tabular}

Uppercase letters in the columns evaluate precompression stresses for the same water content, through the same method in different management systems, while lowercase letters in the rows evaluate precompression stresses in the same management system and method for different water contents, by Tukey test at $5 \%$ of probability; IVI = Intercept void index; DJ\&P= Dias Júnior \& Pierce (1995); TOC = total organic carbon in the soil.

In the system with filter cake application, under the same conditions of volumetric water content, there was a significant reduction $(\mathrm{p}<0.05)$ in pre-compression stress compared with the native forest. However, the increase in volumetric water content in this system did not show significant differences $(\mathrm{p}<0.05)$ for the means of pre-compression stress and values from 49.39 to $74.98 \mathrm{kPa}$ can be observed, which are considered as low to medium according to Horn \& Fleige [14].
In the vinasse application system, it was not possible to obtain $\sigma_{p}$ values at the water content of $0.42 \mathrm{~cm}^{3} \mathrm{~cm}^{-3}$, because it was higher than the saturation water content, according to the soil water retention curve (Figure 3). For the layer of 0-0.20 m, this system showed significant difference in relation to the native forest soil, with stress values between 73.34 and $76.43 \mathrm{kPa}$, not differing statistically from the system with filter cake application. Still for this layer, in all situations, the pre-compression stress tended to de- 
crease in systems with sugarcane cultivation compared with the native forest soil.

For the layer of $0.20-0.40 \mathrm{~m}$ in the soils under native forest and residues of the sugarcane application, the factor water content was not significant for the pre-compression stresses, as well as for the different management systems at the water content of 0.32 $\mathrm{cm}^{3} \mathrm{~cm}^{-3}$. However, for the water contents of 0.36 and $0.42 \mathrm{~cm}^{3} \mathrm{~cm}^{-3}$, there were significant differences $(\mathrm{p}<0.05)$ between the native forest soil and the soils cultivated with sugarcane under filter cake and vinasse application. For the water area of $0.36 \mathrm{~cm}^{3} \mathrm{~cm}^{-3}$, there was a significant reduction of the pre-compressive pressure of the native forest ( $221.18 \mathrm{kPa})$ in relation to the soils cultivated with sugarcane under vinasse and filter cake, which presented respectively $\sigma_{p}$ of 129.75 and $105.75 \mathrm{kPa}$

The mean values of pre-compression stress $(\sigma \mathrm{p})$ dissipated in the cultivated systems (Table 2), in both layers, are close to the values reported by Oliveira et al. [38], in two depths of a Ultisol cultivated with sugarcane. The lowest values for this soil class were reported by Pacheco \& Cantalice [39], studying soils with sugarcane cultivation of 4-14 years, where $\sigma \mathrm{p}$ values from 34 to $48 \mathrm{kPa}$ were observed at the lowest water contents.

\section{Shear strength of soil under drained conditions}

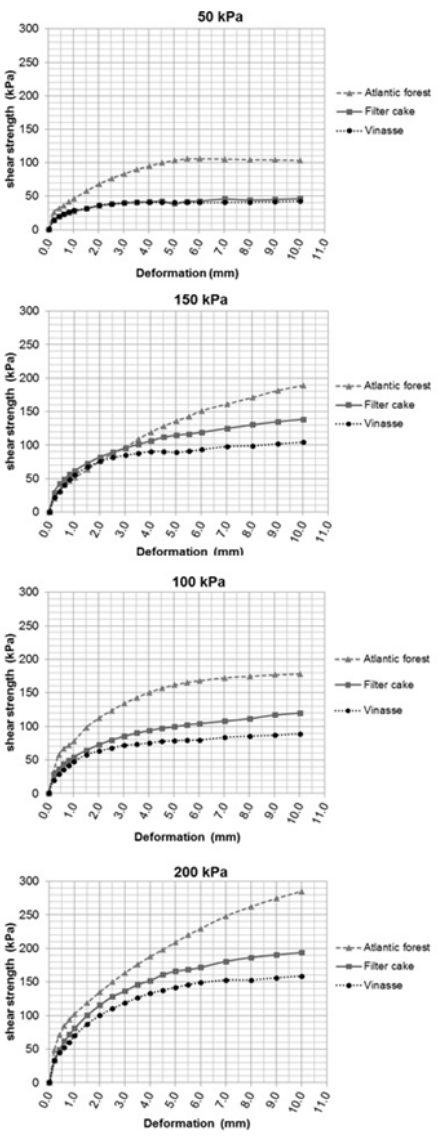

Figure 4: Shear strength of the different management systems in the layer of $0-0.20 \mathrm{~m}$.

Table 3: Cohesion, internal friction angle of an Ultisol under Atlantic forest and sugarcane cultivation with the application of filter cake and vinasse, in the layer of $0-0.20 \mathrm{~m}$.

\begin{tabular}{|c|c|c|c|}
\hline \multirow{2}{*}{ Water Content $\left(\mathrm{cm}^{-3} \mathbf{c m}^{-3}\right)$} & \multicolumn{3}{|c|}{ Management Systems } \\
\cline { 2 - 4 } & Forest Soil & \multicolumn{3}{|c|}{ Filter Cake Soil } & Cohesion (kPa) \\
\cline { 2 - 4 } & & $11.5 \mathrm{Ab}$ & $7.51 \mathrm{Ab}$ \\
\hline 0.32 & $61.23 \mathrm{Aa}$ & $5.4 \mathrm{Ab}$ & - \\
\hline 0.36 & $31.19 \mathrm{Aba}$ & $2.06 \mathrm{Ab}$ & $1.04 \mathrm{~b}$ \\
\hline 0.42 & $22.58 \mathrm{Ba}$ & $1.32 \mathrm{~b}$ & \\
\hline TOC $\left(\mathrm{g} \mathrm{kg}^{-1}\right)$ & $2.42 \mathrm{a}$ & \multicolumn{3}{|c|}{ Vinasse Soil } \\
\hline
\end{tabular}

Means followed by the same letters, uppercase in columns and lowercase in rows, do not differ by Tukey test at $5 \%$ of probability. TOC $=$ total organic carbon in the soil. 
The cohesion values of the management systems ranged from 61.23 to $2.06 \mathrm{kPa}$ (Table 3), with significant differences between the native forest and the other systems cultivated with sugarcane, which did not differ significantly at the same water content. With the decrease in volumetric water content, there was a significant increase in cohesion values (Table 3 ) for the native forest soil, from 22.50 to $61.23 \mathrm{kPa}$. The higher TOC content in the soil under native forest promoted higher cohesion, which allowed the highest shear strength values (Figure 4) compared with the other systems at the same volumetric water content $\left(0.32 \mathrm{~cm}^{3} \mathrm{~cm}^{-3}\right)$, as well as in all normal tensions $(50,100,150$ and $200 \mathrm{kPa})$, with shear strength values from 105.0 to $280.0 \mathrm{kPa}$. Still in Figure 3, the shear strength for the soil cultivated with sugarcane under filter cake application showed higher values from the tension of $100 \mathrm{kPa}$ on (from 120 to $190 \mathrm{kPa}$ ), in relation to the management system with vinasse application, which showed values between 90 and $160 \mathrm{kPa}$.

\section{Simulations of the vertical stress of the agricultural machines in the soil and comparisons with the pre- compression stress}

The highest pressure on the soil surface (Figure 5A) was generated by the tractor's front tires (229 $\mathrm{kPa})$ compared with the rear tires $(215 \mathrm{kPa})$. The smaller width and size of the front tires, com- bined with their higher inflation pressure, compared with the rear ones, led to a decrease in the contact area and, consequently, an increase in the contact pressure on the soil surface.

The tractor used for planting and periodical soil preparation in the selected areas under sugarcane cultivation shows a mean weight of about $49 \mathrm{kN}$ per axle and inflation pressures of approximately $179 \mathrm{kPa}$ and $165 \mathrm{kPa}$ in front and rear tires, respectively. Thus, if the dissipation process promoted by sugarcane residues did not exist, the pressure exerted by the tires would cause an additional compaction to the soil, under the tested conditions, since the pressures of front and rear tires are higher than the pre-compression stress and, consequently, these pressures would occur in the plastic region of the soil. Thus, the soil would suffer an irreversible deformation for water contents above $0.32 \mathrm{~cm}^{3} \mathrm{~cm}^{-3}$ in the layer of 0-0.20 (m) when the machines entered the area.

In Figure 5B, at the depth of $0.25 \mathrm{~m}$, the pressures from rear and front tires were respectively 115 and $95 \mathrm{kPa}$. Thus, the relation between the load applied on soil surface and the evaluated layer corresponds to $2.4: 1$ for the front tires and 1.8:1 for the rear tires. Therefore, the pressure dissipated until the depth of $0.25 \mathrm{~m}$ corresponded to $58 \%$ for the front tires and $48 \%$ for the rear tires.
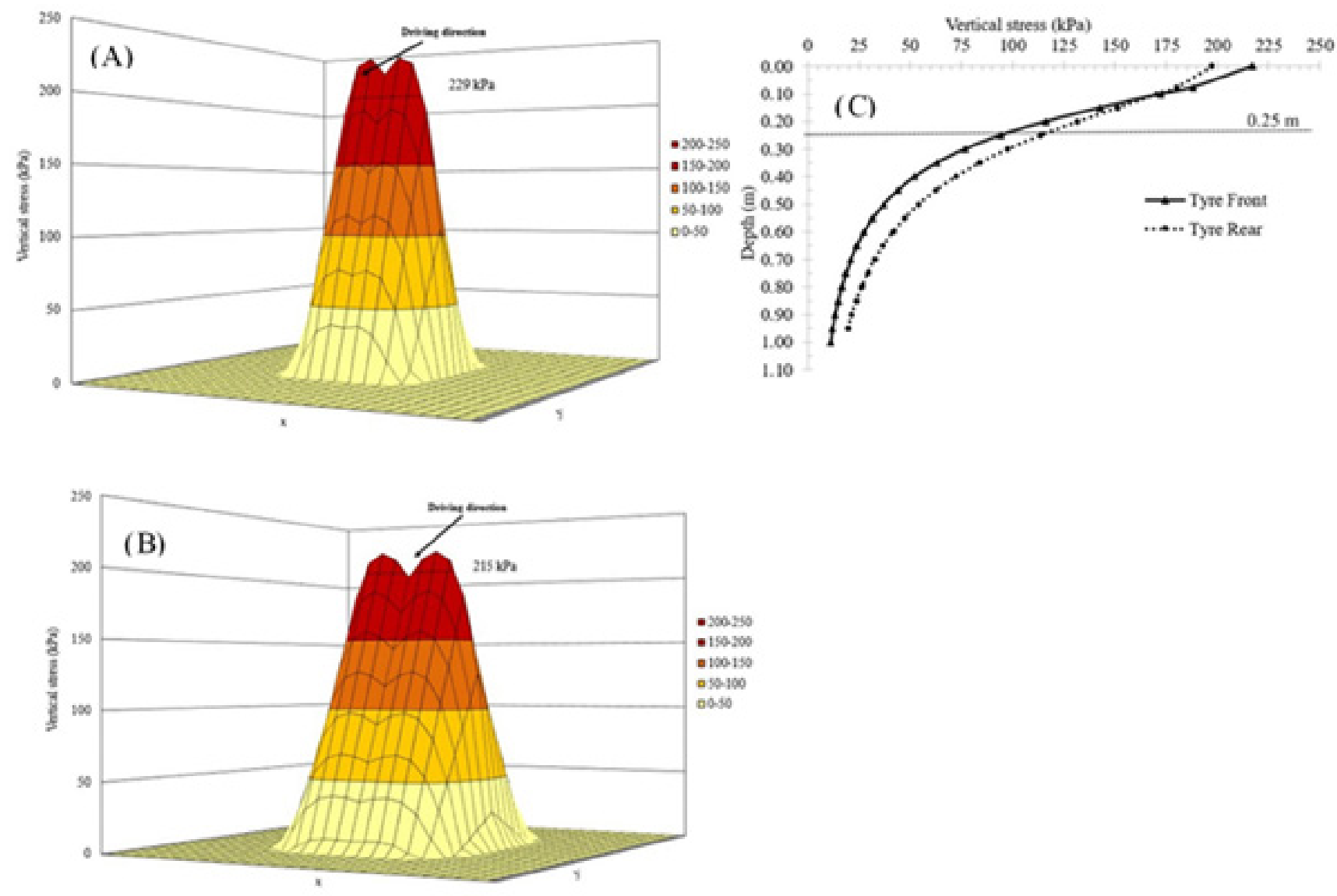

Figure 5: Pressures on soil surface generated by the front $(A)$ and rear tires $(B)$ of the $\mathrm{BH} 180$ tractor. 
In the layer of $0-0.20 \mathrm{~m}$, the values of pre-compression stress in the system with filter cake application are lower than the pressure exerted by machines on the soil surface. However, in the layer of $0.20-0.40 \mathrm{~m}$, most of the pre-compression stresses at all water contents are higher than the pressure exerted by the machines.

\section{Discussion}

\section{Pre-compression stress ( $\sigma \mathrm{p})$ and prediction relations}

The native forest system, where the lowest soil density was observed (Table 1), was expected to show the lowest pre-compression stresses for the studied soil class, as reported by Pacheco \& Cantalice [39], Vasconcelos \& Cantalice [2] and Oliveira et al. [38], since the external pressure from the agricultural machines are higher than the pre-compression stress in the cultivated areas of this study (Figure 5). In addition, under high moisture conditions, these two factors cause a more dense packing of soil mineral particles, which reduces the amount of pores (macropores) and consequently promote a higher number of contact points between the particles, because, according to Gupta et al. [40], this can result in a new state of resistance to external pressures. However, in the native forest soil, the organic matter caused an increase in soil resistance to compression due to the predominance of the effect of increase in shear strength parameters (cohesion), increase of capillary tension with the increase of the apparent cohesion.

According as observed in the Table 1, all these are grouped as medium texture soils according to EMBRAPA [37]. Soils of cultivated areas have different contents of clay in depth of 0-0.20m However, in all situations, the silt + clay values of the filter cake system (391.80 $\mathrm{gkg}^{-1}$ ) and vinasse (381.55 $\mathrm{gkg}^{-1}$ ) are higher than $300 \mathrm{gkg}^{-1}$, so the mechanical behavior in these systems Is influenced by the finer fractions of the soil. Chik \& Villajo [41] report that in soils where silt + clay fractions are greater than $300 \mathrm{~g} \mathrm{~kg}-1$ the finer fractions govern mechanical processes, and Monkul \& Ozden [42] concluded that the interval between $190-340 \mathrm{gkg}^{-1}$ in the contents of silt + clay correspond to the ideal transition range of the mechanical behavior of sandy soils to clayey soils. Thus, in comparison to soil under Atlantic forest ( $480.67 \mathrm{gkg}^{-1}$ of clay) it may be affirm wich the systems present same mechanical behavior as to influence of the granulometric fractions on soil mechanic in study.

Thereby, is evident which the lowest values of pre-compression stress in the management systems with filter cake and vinasse application (Table 2) showed the effect of the application of these residues on the process of dissipation of pressures applied to the soil. As reported by Braida [6], the application of plant residues on the soil surface absorbs part of the compaction energy generated using agricultural machines, because the transfer of compaction energy does not occur during residue deformation. Thus, the lowest values of pre-compression stress in the management systems with filter cake and vinasse application showed that sugarcane fibers in these residues, applied for a period of 25 years, were able to dissipate the compaction energy through their deformation, and that the dissipation of compaction energy can be effective for long periods, or at least for 25 years.

\section{Reactions of direct shear strength of the Ultisols under different sugarcane managements in the superficial layer}

The higher TOC content in the soil under native forest resulted in an increase of soil cohesion in the layer of $0-0.20 \mathrm{~m}$ (Table 3 ). The higher OM content in the native forest, compared with the cultivated soils, possibly promoted an increase in the forces of bonds and/or the establishment of new bonds between soil particles, whether through physical and chemical characteristics of organic molecules or through particle aggregation produced by organic filaments, like fungal hyphae and roots, as mentioned by Soane [43]. Given the above, the increase in soil cohesion not only reflected in the increase in shear strength of this soil (Figure 4), but also in the increase of pre-compression stress in relation to the cultivated soils under vinasse and filter cake application (Table 2), since the increase in soil resistance due to $\mathrm{OM}$ will depend on the balance between its joint effects on soil density, shear parameters, capillary tension and the degree of saturation by water [44].

The system with filter cake application showed higher shear strength compared with the system with vinasse application (Figure 4). This can be related to the presence of cellulosic fibers from the filter cake, since according to Gao \& Zhao [45], the shear strength of a soil with the presence of fibers is due to two factors: one inherent to soil properties and the other inherent to the fiber itself, for its tensile resistance. Given the nature of the fiber-soil interaction, the response to shearing in the system with filter cake application was strongly influenced by the incorporation of longer fibers in the soil matrix, compared with the system with vinasse application. Therefore, according to Cristelo et al. [46], soil particles transfer normal and shearing stresses to the surface of the fiber, which is stretched until its rupture resistance; only after this, soil particles are totally mobilized, and the fiber contributes to the increase in shear strength. This increase in resistance occurs because organic fibers have higher degree of elasticity. According to Horn [47], these materials, under compression forces, show higher degrees of elasticity compared to soil mineral particles.

The results for shear strength in the filter cake system, when compared with the vinasse system, agree with others in the literature on incorporation of organic fibers for the improvement of soil shear strength, as observed in Prabakar \& Sridhar [48]. These authors obtained good results in the increase of soil resistance with the incorporation of up to $0.75 \%$ of sisal fibers in the soil matrix [49-52].

\section{Conclusion}

The pressures applied on soil surface by the tires of agricultural machines were higher than the pre-compression stress of the studied management systems. However, the application of sugarcane 
organic residues in the form of vinasse and filter cake allowed good results in the process of pressure dissipation in the areas cultivated with sugarcane, which showed the lowest pressures compared with Atlantic forest soil at all water contents evaluated.

The highest content of soil organic carbon in the soil under Atlantic forest favored the increase in soil cohesion and consequently the increase in soil shear strength, making it less susceptible to deformations. On the other hand, in the soils under cultivation, the presence of organic fibers from filter cake favored an increase in shear strength compared with the soil under vinasse application.

\section{Acknowledgement}

None.

\section{Conflict of Interest}

No conflict of interest.

\section{References}

1. Bouma J (2015) Reaching out from the soil-box in pursuit of soil security. Soil science and plant nutrition 61(4): 556-565.

2. Nkonya E, Gerber N, Baumgartner P, von Braun J, De Pinto A, et al. (2011) The economics of desertification, land degradation, and drought toward an integrated global assessment. ZEF-Discussion Papers on Development Policy (150), pp. 196.

3. Lal R (2012) Climate change and soil degradation mitigation by sustainable management of soils and other natural resources. Agricultural Research 1(3): 199-212.

4. De Long C, Cruse RM, Wiener J (2015) The soil degradation paradox: compromising our resources when we need them most. Sustainability 7: 866-879.

5. Foran T (2015) Node and regime: Interdisciplinary analysis of waterenergy-food nexus in the Mekong region. Water Alternatives 8(1).

6. Wolfe ML, Ting KC, Scott N, Sharpley A, Jones JW, et al. (2016) Engineering solutions for food-energy-water systems: it is more than engineering. Journal of Environmental Studies and Sciences 6(1): 172-182.

7. Albrecht TR, Crootof A, Scott CA (2018) The Water-Energy-Food Nexus: A systematic review of methods for nexus assessment. Environmental Research Letters 13(4): 043002.

8. Hatfield JL, Sauer TJ, Cruse RM (2017) Soil: The forgotten piece of the water, food, energy nexus. Academic Press. In Advances in Agronomy 143: 1-46.

9. Lal R (2010) Enhancing eco-efficiency in agro-ecosystems through soil carbon sequestration. Crop Sci 50: 120-131.

10. Gomiero T, Pimentel D, Paoletti MG (2011) Is there a need for a more sustainable agriculture? Critical reviews in plant sciences 30(1-2): 6-23.

11. Reynolds JF, Maestre FT, Kemp PR, Stafford-Smith DM, Lambin E (2007) Natural and human dimensions of land degradation in drylands: causes and consequences. In Terrestrial ecosystems in a changing world, Springer, Berlin, Heidelberg, pp. 247-257.

12. UN (United Nations) (2013) Draft Resolution Submitted by the ViceChair of the Committee, Ms. Farrah Brown (Jamaica), on the Basis of Informal Consultations on Draft Resolution A/C.2/68/L.21, United Nations General Assembly: Washington, DC, USA.

13. Keesstra SD, Bouma J, Wallinga J, Tittonell P, Smith P, et al. (2016) The significance of soils and soil science towards realization of the United Nations Sustainable Development Goals. Soil 2: 111-128.

14. Helming K, Daedlow K, Hansjürgens B, Koellner T (2018) Assessment and Governance of Sustainable Soil Management. Sustainability 10(12): 4432
15. Rockström J, Williams J, Daily G, Noble A, Matthews N, et al. (2017) Sustainable intensification of agriculture for human prosperity and global sustainability. Ambio 46(1): 4-17.

16. Tittonell P (2014) Ecological intensification of agriculture-sustainable by nature. Current Opinion in Environmental Sustainability 8: 53-61.

17. Birner R (2018) Bioeconomy concepts. In: Lewandowski I (ed.). Bioeconomy: shaping the transition to a sustainable, biobased economy. Springer Nature Switzerland, pp. 17-38.

18. Ho A, Ijaz UZ, Janssens TK, Ruijs R, Kim SY, de Boer W, et al. (2017) Effects of bio-based residue amendments on greenhouse gas emission from agricultural soil are stronger than effects of soil type with different microbial community composition. Gcb Bioenergy 9(12): 1707-1720.

19. Lampkin NH, Pearce BD, Leake AR, Creissen H, Gerrard CL, et al. (2015a) The role of agroecology in sustainable intensification. ORC Bulletin. No. 119 - Autumn/Winter.

20. Lampkin NH, Pearce BD, Leake AR, Creissen H, Gerrard CL, et al. (2015b) The role of agroecology in sustainable intensification. Report for the Land Use Policy Group. Organic Research Centre, Elm Farm and Game \& Wildlife Conservation Trust.

21. Luo G, Li L, Friman VP, Guo J, Guo S, Shen Q, et al. (2018) Organic amendments increase crop yields by improving microbe-mediated soil functioning of agroecosystems: A meta-analysis. Soil Biology and Biochemistry 124: 105-115.

22. Wessuc (2018) Winter Spreading and Biosolids- Sewage Biosolids. Waste management service in Brant, Ontario.

23. OMAFRA (2020) Sewage biosolids- managing urban nutrients responsibly for crop production. Ministry of Agriculture, Food and Rural Affairs, Ontario, Canada.

24. Halloran S (2020) Do you have a question about Biosolids or Organics? Lystek.org.

25. Drury CF, Reynolds WD, Yang XM, Tan CS, Guo X, et al. (2014) Influence of compost source on corn grain yields, nitrous oxide and carbon dioxide emissions in southwestern Ontario. Canadian Journal of Soil Science 94(3): 347-355

26. Wang H, Brown SL, Magesan GN, Slade AH, Quintern M, et al. (2008) Technological options for the management of biosolids. Environmental Science and Pollution Research-International 15(4): 308-317.

27. Quilty JR, Cattle SR (2011) Use and understanding of organic amendments in Australian agriculture: a review. Soil Research 49(1): $1-26$.

28. Odlare M, Pell M, Svensson K (2008) Changes in soil chemical and microbiological properties during 4 years of application of various organic residues. Waste management 28(7): 1246-1253.

29. Boldrin A, Andersen JK, Møller J, Christensen TH, Favoino E (2009) Composting and compost utilization: accounting of greenhouse gases and global warming contributions. Waste Management \& Research 27(8): 800-812.

30. Brundtland GH (1987) Brundtland Report. Our Common Future. Comissão Mundial.

31. Sustainable Measures (2010) Sustainability Indicators 101: Indicators for sustainability.

32. Living Planet Report (2014) World wildlife (WWF) Living Planet Report 2014

33. Dryzek J (2013) The Politics of the Earth. Environmental Discourses (Oxford).

34. Orr DW (2002) The Nature of Design: Ecology, Culture, and Human Intention, Oxford University Press, p. 29.

35. Thangarajan R, Bolan NS, Tian G, Naidu R, Kunhikrishnan A (2013) Role of organic amendment application on greenhouse gas emission from soil. Science of the Total Environment 465: 72-96.

36. Liu X, Wang Q, Qi Z, Han J, Li L (2016) Response of $\mathrm{N}_{2} \mathrm{O}$ emissions to biochar amendment in a cultivated sandy loam soil during freeze-thaw cycles. Scientific reports 6: 35411 . 
37. Chantigny MH, Bittman S, Larney FJ, Lapen D, Hunt DE, et al. (2019) A multi-region study reveals high overwinter loss of fall-applied reactive nitrogen in cold and frozen soils. Canadian Journal of Soil Science 99(2): 126-135.

38. Paustian K, Lehmann J, Ogle S, Reay D, Robertson GP, et al. (2016) Climate-smart soils. Nature 532(7597): 49-57.

39. Urra J, Alkorta I, Garbisu C (2019) Potential Benefits and Risks for Soil Health Derived from the Use of Organic Amendments in Agriculture. Agronomy 9(9): 542

40. Borlaug N (1970) Norman Borlaug - Nobel Lecture.

41. Altieri MA, Nicholls CI (2012) Agroecology scaling up for food sovereignty and resiliency. In Sustainable agriculture reviews. Springer, Dordrecht, pp. 1-29.

42. Gliessman SR (2014) Agroecology: the ecology of sustainable food systems. CRC press.

43. Garini CS, Vanwindekens F, Scholberg JMS, Wezel A, Groot, JC (2017) Drivers of adoption of agroecological practices for winegrowers and influence from policies in the province of trento, italy. Land Use Policy 68: 200-211.

44. Leopold A (1970) A sand county almanac: With other essays on conservation from Round River. Outdoor Essays \& Reflections.

45. Hathaway MD (2016) Agroecology and permaculture: addressing key ecological problems by rethinking and redesigning agricultural systems. Journal of Environmental Studies and Sciences 6(2): 239-250.

46. Amon B, Kryvoruchko V, Amon T, Zechmeister-Boltenstern S (2006) Methane, nitrous oxide and ammonia emissions during storage and after application of dairy cattle slurry and influence of slurry treatment Agriculture, ecosystems \& environment 112(2-3): 153-162.

47. Saletnik B, Zaguła G, Bajcar M, Tarapatskyy M, Bobula G, et al. (2019) Biochar as a Multifunctional Component of the Environment-A Review. Applied Sciences 9(6): 1139.

48. Adegbeye MJ, Reddy P, Kanth R, Obaisi AI, Elghandour MM, et al. (2020) Sustainable agriculture options for production, greenhouse gasses and pollution alleviation, and nutrient recycling in emerging and transitional nations-An overview. Journal of Cleaner Production 242: 118319.

49. Meier S, Curaqueo G, Khan N, Bolan N, Cea M, et al. (2017) Chickenmanure-derived biochar reduced bioavailability of copper in a contaminated soil. Journal of Soils and Sediments 17(3): 741-750.

50. Yamashita T, Shiraishi M, Yokoyama H, Ogino A, Yamamoto-Ikemoto $\mathrm{R}$, et al. (2019) Evaluation of the Nitrous Oxide Emission Reduction Potential of an Aerobic Bioreactor Packed with Carbon Fibres for Swine Wastewater Treatment. Energies 12(6): 1013.

51. De Molina MG (2013) Agroecology and politics. How to get sustainability? About the necessity for a political agroecology. Agroecology and Sustainable Food Systems 37(1): 45-59.

52. Lomba A, Strohbach M, Jerrentrup IS, Dauber J, Klimek S, et al. (2017) Making the best of both worlds: Can high-resolution agricultural administrative data support the assessment of High Nature Value farmlands across Europe? Ecological indicators 72: 118-130.

53. Mang H, (2015) How the Chinese are turning human waste into 'black gold'.

54. Beaton J (2009) History of fertilizer. Efficient Fertilizer Use Manual, Mosaic Back to Basics, Plymouth, Minnesota, USA.

55. Wild A (1988) Historical. In: Wild, A. (Ed.), Russell's Soil Conditions and Plant Growth, eleventh ed. Longman Scientific \& Technical, Harlow, Essex, UK, pp. 1-30.

56. Allison RV (1944) The Original Field Plot Studies at Rothamsted 1. Soil Science Society of America Journal 8(C): 6-11.

57. Dyke GV (1993) John Lawes of Rothamsted. Pioneer of Science, Farming and Industry. Hoos Press, Harpenden, UK.
58. Goss MJ, Tubeileh A, Goorahoo D (2013) A review of the use of organic amendments and the risk to human health. In Advances in agronomy 120: 275-379.

59. Lal R (2011) Soil health and climate change: an overview. In Soil health and climate change (pp. 3-24). Springer, Berlin, Heidelberg.

60. Schlesinger WH, Amundson R (2019) Managing for soil carbon sequestration: Let's get realistic. Global change biology 25(2): 386-389.

61. Yadav V, Karak T, Singh S, Singh AK, Khare, P (2019) Benefits of biochar over other organic amendments: Responses for plant productivity (Pelargonium graveolens L.) and nitrogen and phosphorus losses. Industrial Crops and Products 131: 96-105.

62. Chenu C, Angers DA, Barré P, Derrien D, Arrouays D, et al. (2019) Increasing organic stocks in agricultural soils: Knowledge gaps and potential innovations. Soil and Tillage Research 188: 41-52.

63. Lal R (2008) Carbon sequestration, Philos. T Roy Soc B 363: 815-830.

64. Allen DE, Singh BP, Dalal RC (2011) Soil health indicators under climate change: a review of current knowledge. In Soil health and climate change, Springer, Berlin, Heidelberg, pp. 25-45.

65. Sanderman J, Hengl T, Fiske GJ (2017) Soil carbon debt of 12,000 years of human land use. Proceedings of the National Academy of Sciences 114(36): 9575-9580.

66. Assad ED, Pinto HS, Martins SC, Groppo JD, Salgado PR, et al. (2013) Changes in soil carbon stocks in Brazil due to land use: paired site comparisons and a regional pasture soil survey. Biogeosciences 10: 6141-6160.

67. Murphy BW (2015) Impact of soil organic matter on soil properties-a review with emphasis on Australian soils. Soil Research 53(6): 605-635.

68. Wise TA (2013) Can we feed the world in 2050. A scoping paper to assess the evidence. Global Development and Environment Institute Working Paper, (13-04). Tufts University. 38 p.

69. Smith P, Gregory PJ, Van Vuuren D, Obersteiner M, Havlík P, et al. (2010) Competition for land. Philosophical Transactions of the Royal Society B: Biological Sciences 365(1554): 2941-2957.

70. Tilman D, Balzer C, Hill J, Befort BL (2011) Global food demand and the sustainable intensification of agriculture. Proceedings of the national academy of sciences 108(50): 20260-20264.

71. Campbell BM, Thornton P, Zougmoré R, Van Asten P, Lipper L (2014) Sustainable intensification: What is its role in climate smart agriculture? Current Opinion in Environmental Sustainability 8: 39-43.

72. Maiti SK, Ahirwal J (2019) Ecological Restoration of Coal Mine Degraded Lands: Topsoil Management, Pedogenesis, Carbon Sequestration, and Mine Pit Limnology. In Phytomanagement of Polluted Sites, Elsevier, pp. 83-111.

73. Alvarenga P, Mourinha C, Farto M, Santos T, Palma P, et al. (2015) Sewage sludge, compost and other representative organic wastes as agricultural soil amendments: Benefits versus limiting factors. Waste management 40: 44-52.

74. El-Naggar A, Lee SS, Rinklebe J, Farooq M, Song H, et al. (2019) Biochar application to low fertility soils: a review of current status, and future prospects. Geoderma 337: 536-554.

75. Tsagaraki E, Karachaliou E, Delioglanis L, Kouzi E (2017) D2.1 Bio-based products and applications potential. (Q-PLAN).

76. European Commission (2020) Bioeconomy policy: Policy background, strategy and contribution to the Commission's political agenda of bioeconomy policy.

77. BECOTEPS (2011) The European Bioeconomy in 2030: Delivering sustainable growth by addressing the Grand Societal Challenges.

78. Piotrowski S, Carus M, Carrez D (2016) European Bioeconomy in figures. Commissioned by Bio-based Industries Consortium. 